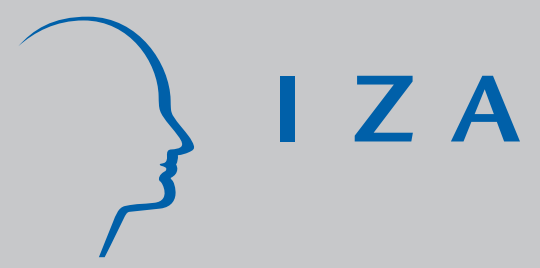

IZA DP No. 766

How Important Is Guaranteed or Institutionalised Overtime?

David N. F. Bell

Robert A. Hart

April 2003 


\title{
How Important Is Guaranteed or Institutionalised Overtime?
}

\author{
David N. F. Bell \\ University of Stirling \\ Robert A. Hart \\ University of Stirling and IZA Bonn
}

Discussion Paper No. 766

April 2003

\author{
IZA \\ P.O. Box 7240 \\ D-53072 Bonn \\ Germany \\ Tel.: +49-228-3894-0 \\ Fax: +49-228-3894-210 \\ Email: iza@iza.org
}

This Discussion Paper is issued within the framework of IZA's research area The Future of Labor. Any opinions expressed here are those of the author(s) and not those of the institute. Research disseminated by IZA may include views on policy, but the institute itself takes no institutional policy positions.

The Institute for the Study of Labor (IZA) in Bonn is a local and virtual international research center and a place of communication between science, politics and business. IZA is an independent, nonprofit limited liability company (Gesellschaft mit beschränkter Haftung) supported by the Deutsche Post AG. The center is associated with the University of Bonn and offers a stimulating research environment through its research networks, research support, and visitors and doctoral programs. IZA engages in (i) original and internationally competitive research in all fields of labor economics, (ii) development of policy concepts, and (iii) dissemination of research results and concepts to the interested public. The current research program deals with (1) mobility and flexibility of labor, (2) internationalization of labor markets, (3) welfare state and labor market, (4) labor markets in transition countries, (5) the future of labor, (6) evaluation of labor market policies and projects and (7) general labor economics.

IZA Discussion Papers often represent preliminary work and are circulated to encourage discussion. Citation of such a paper should account for its provisional character. A revised version may be available on the IZA website (www.iza.org) or directly from the author. 
IZA Discussion Paper No. 766

April 2003

\section{ABSTRACT \\ How Important Is Guaranteed or Institutionalised Overtime?*}

Basing our empirical work on the British New Earnings Survey Panel Data between 1990 and 1996, we show that overtime hours of male workers contain significant individual effects. We also show that using suitable techniques to deal with the lagged overtime variable serves to alter radically the estimated speed of adjustment of overtime to its desired level. Our results are consistent with firms either guaranteeing the length of weekly overtime or following institutionalised custom and practice in their overtime arrangements. They are far less supportive of traditional demand-side analyses of overtime working.

JEL Classification: J22, J23

Keywords: overtime hours, individual effects, GMM estimation

Corresponding author:

Robert A. Hart

Department of Economics

University of Sterling

Stirling, FK9 4LA

United Kingdom

Email: r.a.hart@stir.ac.uk

\footnotetext{
${ }^{*}$ We are grateful to Stephen Bond and Sergi Jimenez-Martin for advice on the approach to estimation. Work on this paper was funded under ESRC grant R 000223442.
} 


\section{Introduction}

Overtime working is commonly regarded as a short-term employment adjustment mechanism that enables firms to meet unexpected variations in demand without incurring the fixed costs of hiring or firing workers (e.g. Bils, 1987). Yet there is a view that many firms employ overtime hours irrespective of the state of demand. ${ }^{1}$ Such hours are described as guaranteed overtime when they are directly incorporated in workers' contracts and as institutionalised overtime when they come about as a result of custom and practice. The UK government in its interpretation of the European Union Working Time Regulations has acknowledged the existence of such hours. Thus, normal hours of work are defined as those hours that "do not include overtime except guaranteed overtime" (Department of Trade and Industry, 1998). There appears to be no direct empirical work on this form of overtime working. This paper attempts to fill this gap in the working time literature. It turns out that the conclusions have strong implications for an earlier literature concerned with the modelling of workers and hours.

While the assumption that overtime working is a short-run response to demand fluctuations is common, there are models of hours and wages that provide a different emphasis. The most influential of these is the so-called fixed job model of Lewis (1969) (see also Rosen, 1974). The firm and its workers jointly determine wages and hours that define long-run contractual wage earnings. If the government mandates the maximum

\footnotetext{
${ }^{1}$ Based on a series of case studies, Incomes Data Services (1999 and 2002) report that a number of British manufacturing firms have attempted to circumvent an 'overtime culture' by seeking alternative contractual arrangement with their employees. So-called Annualised Hours' Contracts are of particular interest in this context.
} 
number of standard weekly or daily hours, then equilibrium wage earnings may involve a permanent element of overtime working. The government may also set the minimum level of the overtime premium. In this event, a mandated premium increase will involve the parties re-setting the standard wage rate so as to leave hours (standard and overtime) and wage earnings at agreed contracted levels (Trejo, 1991). Extending this reasoning to an economy with voluntary overtime practices, we provide a rationale for expecting to observe individual (or job-match) effects in overtime working that do not change through time. It is these, we argue, that underpin the notions of guaranteed and institutionalised overtime working.

Our empirical work is designed to investigate the significance of these individual effects as well as their implications for the conventional demand analysis of overtime hours. It is based on overtime statistics contained in the British New Earnings Survey Panel Data (NESPD) from 1990 to 1996, a period during which the economy experienced a sharp recession and then sustained recovery. Thus, to the extent that product demand fluctuations are important, these are by no means 'suppressed' in our data.

\section{Individual Effects in Overtime Working}

Even in labour markets like Britain where statutory overtime rules do not apply, it would appear that overtime hours and pay are not wholly geared to meeting short-term shifts in production requirements. The maximum lengths of standard weekly hours set by many firms follow wider industrial or regional or national collective bargaining norms. British overtime premia, as shown by Hart and Ruffell (1993) and Bell and Hart (2003), is independent of overtime hours. These observations are consistent with the view that the 
conditions for overtime working follow 'custom and practice'. This can be rationalised in the following way. If both the hourly wage rate and the premium are set within long-term efficient contracts then overtime premia are indeterminate. To resolve this problem, firms and workers simply resort to an established 'norm' for setting the rate of overtime pay; the premium is set permanently at the standard hourly rate plus one-half or one-third or one-quarter. ${ }^{2}$ A similar line of reasoning applies to agreements to set the length of the standard workweek in accord with wider industrial or geographical or collective bargaining practices. Further, Bell and Hart (2003) show that the standard hourly wage is negatively related to overtime hours while the average hourly wage (averaged over standard and overtime hours) is constant in overtime hours. These findings are not consistent with the marginal cost of labour increasing in labour utilisation at the individual level.

One way of rationalising a constant average hourly wage is that firms offer jobs of fixed hourly lengths. Technical, organisational and customer service constraints vary across firms and require different firms to require different fixed lengths of daily or weekly hours. Since many firms take the length of the standard workweek as given, those requiring longer weekly hours will inevitably incorporate overtime within total weekly hours. Overtime premia are set independently of the length of overtime hours. Yet, firms set a going competitive average hourly wage rate. This requires that, for given overtime

\footnotetext{
${ }^{2}$ For a number of British case studies, from a broad spectrum of manufacturing and service companies, see Incomes Data Services (1997). Some firms apply different rates to different parts of the workweek - for example, a higher rate may apply to weekend compared to weekday overtime hours - but this does not affect our argument.
} 
hours, lower standard rates will be used to offset high premiums. For given premium rates, the cost of long overtime hours will also be offset by lower standard rates. Firms then let workers match to the jobs that best represent their work/leisure preferences. In other words, for given job specifications, average hourly pay is constant across jobs but workers are able to control their weekly earnings by selecting the length of job that best matches their supply-side preferences.

Of course, we recognise that short-run demand perturbations and other random events (like absences due to sickness) may require temporary deviations from fixed job lengths. We argue, however, that the level of overtime working only partially reflects such hours' disturbances. In fact, from an empirical standpoint, we show below that these effects are potentially grossly exaggerated in models that fail to account for individual effects.

In summary, we conjecture that overtime hours and remuneration largely follow custom and practice. The average hourly wage rate is constant in overtime hours. Individuals select jobs of fixed weekly lengths depending on their work/leisure preferences. These conditions imply that we should expect to observe individual effects in workers' overtime hours that correspond to particular worker/job matches.

It is these conditions, we believe, that underscore the popular notions that overtime working contains important guaranteed or institutionalised elements. 


\section{Modelling overtime hours}

Let overtime hours for individual i at time $t, v_{i t}$, be expressed by the identity

$$
v_{i t}=h_{i t}-h s_{i t}
$$

where $h_{i t}$ is weekly total hours and $h s_{i t}$ is maximum weekly standard hours. Our basic overtime equation is expressed in levels. It takes the form

$$
v_{i t}=c_{t}+\alpha v_{i, t-1}+\beta x_{i t}+\left(\lambda_{i}+\varepsilon_{i t}\right)
$$

where $c_{t}$ is a year-specific intercept to account for common cyclical or trend components, $v_{i, t-1}$ is the overtime observation on the same individual in the previous period, $x_{i t}$ is a vector of current and lagged values of additional explanatory variables, $\alpha$ and $\beta$ are constants, $\lambda_{i}$ is an unobserved individual (job-match) effect, and $\varepsilon_{i t}$ is a disturbance term. We include the length of weekly standard hours, the lagged standard hourly wage rate and industry dummies in $x$. The hours' specification in (2) nests a traditional demandside model of hours determination (Ehrenberg, 1971) where the coefficient $\alpha$ is taken to measure the speed of response of actual to desired hours input (e.g. Nadiri and Rosen, 1973; Topel, 1982).

The individual effects, $\lambda_{i}$ associated with individual $i$ are intended to capture job match effects on overtime hours. Individual preferences will result in some workers wishing to work long overtime hours. They will seek to find a match with firms that 'guarantees' such hours. Our empirical testing focuses on the importance of these effects. In particular, we construct a test to determine whether such individual effects are important in the context of a dynamic panel model. We discuss this test in the next section. The 
investigation also examines implications of allowing for individual effects for the coefficient on the lagged dependent variable, $\alpha$ in (2), which has traditionally been taken as the indicator of the response speed of hours to demand-side shocks.

\section{Individual effects in dynamic panel models}

In the presence of individual effects, OLS estimates of (2) will be inconsistent because of the correlation between these effects and lagged overtime. The estimates are likely to be upward biased due to standard omitted variables considerations. Such bias will lead to an underestimate of the speed of adjustment of overtime hours. Taking deviations from individual means eliminates the individual effects, but does not remove the correlation between the lagged dependent variable and the (transformed) error term, at least for small T. In this case, the correlation is likely to be negative. This suggests that the "within" estimator, which is commonly used in static panel models, will be inconsistent, with the direction of bias likely to be negative.

Provided the disturbances $\left(\varepsilon_{i t}\right)$ are serially uncorrelated, a consistent estimator can be derived by transforming the data using either first differences or orthogonal deviations to eliminate individual effects ${ }^{3}$ and then applying instrumental variables. Relevant instruments may include levels of the dependent variable lagged two periods or more and predetermined variables. The lack of serial correlation in the disturbances can be tested by checking for the existence of second-order autocorrelation in the differenced residuals.

\footnotetext{
${ }^{3}$ For a description of the orthogonal deviations transformation see Arellano (1993).
} 
Appropriate instruments are $Z_{i}=\left[\begin{array}{cccccccc}v_{i 1} & 0 & 0 & . . & 0 & 0 & 0 & 0 \\ 0 & v_{i 1} & v_{i 2} & . . & 0 & 0 & 0 & 0 \\ . . & . . & . . & . . & . . & . . & . . & . . \\ 0 & 0 & 0 & . . & v_{i 1} & . . & . . & v_{i T-2}\end{array}\right]$ where the rows correspond to the first-differenced equations for periods $t=3,4, \ldots \mathrm{T}$. Asymptotic efficiency can be achieved by applying Hansen's (1982) Generalised Method of Moments (GMM) estimator to conditions such as $E\left[Z_{i}^{\prime} \Delta \varepsilon_{i}\right]=0 \quad i=1 \ldots N$ where $\Delta \varepsilon_{i}=\left(\Delta \varepsilon_{i 3} \Delta \varepsilon_{i 4} . . \Delta \varepsilon_{i T}\right)^{\prime}$. A two-step estimator is required to achieve efficiency, the first step being used to provide consistent estimates of the first-differenced residuals that are then used to form the weighting matrix $W_{N}$. The estimates are then formed by minimising the criterion function

$$
J=\left(\frac{1}{N} \sum_{i=1}^{N} \Delta \varepsilon_{i}^{\prime} Z_{i}\right) W_{N}\left(\frac{1}{N} \sum_{i=1}^{N} Z_{i}^{\prime} \Delta \varepsilon_{i}\right)
$$

(for details see Arellano and Bond 1991). Arellano and Bover (1995) show that efficiency can be increased by stacking the first difference equation described above on top of an equivalent levels formulation and then jointly solving for the unknown parameters. First differences (or orthogonal deviations) of the dependent variable, appropriately lagged, are valid instruments for a levels specification such as equation (2). A test of the joint significance of the individual effects can be constructed by testing the null hypothesis $\operatorname{var}\left(\lambda_{i}\right)=0$ against the alternative $\operatorname{var}\left(\lambda_{i}\right)>0$. Following Holtz-Eakin (1988), Arellano (1993) and Jimenez-Martin (1998) we note that under the null hypothesis, the first differences and levels equations produce consistent estimates of $\delta=\left[\begin{array}{ll}\alpha & \beta^{\prime}\end{array}\right]^{\prime}$ whereas under the alternative, the levels specification is not valid. We can therefore base a test for the existence of individual effects on the presence or absence of 
orthogonality between the errors in levels and the dependent variable. The estimating equation is

$$
V_{i}=\left[\begin{array}{c}
\Delta v_{i} \\
v_{i}
\end{array}\right]=\left[\begin{array}{cc}
\Delta r_{i} & 0 \\
0 & r_{i}
\end{array}\right] \delta+\left[\begin{array}{c}
\Delta \varepsilon_{i} \\
\varepsilon_{i}
\end{array}\right]=R_{i} \delta_{i}+\mathrm{E}_{i} \quad i=1 \ldots N
$$

where $r_{i}=\left\lfloor v_{i, t-1} x_{i}\right\rfloor$. In Jiminez-Martin's (1998) notation ${ }^{4}$, the appropriate instruments are $Z_{i}^{L D}=\left[\begin{array}{cc}Z_{i}^{D} & 0 \\ 0 & Z_{i}^{L}\end{array}\right]$ where the superscripts $D, L$ and $L D$, refer respectively to differenced, levels and combined levels and differences versions of the instrument matrix $Z_{i}$. The efficient GMM estimator of this system minimises the criterion $J^{L D}=\left(\frac{1}{N} \sum_{i=1}^{N} \hat{\mathrm{E}}_{i}^{\prime} Z_{i}^{L D}\right) W_{N}\left(\frac{1}{N} \sum_{i=1}^{N} Z_{i}^{L D^{\prime}} \hat{\mathrm{E}}_{i}\right)$ which is distributed as $\chi_{q}^{2}$ where $\mathrm{q}$ is the number of overidentifying restrictions - a standard Sargan test. Calculating a similar statistic, $J^{D}$, under the alternative enables the construction of a Sargan difference (or pseudo-likelihood ratio) test of our null hypothesis i.e. $J=J^{L D}-J^{D} \sim \chi_{q-r}^{2}$ where $\mathrm{r}$ is the number of overidentifying restrictions associated with the alternative. Following JiminezMartin (1998), $J^{D}$ is calculated by using the residuals from the first step of a combined levels and differences estimate to create a new weighting matrix $B^{D}$, which is then used in the second-step estimation of the first-differences equation ${ }^{5}$. We now consider our results.

\footnotetext{
${ }^{4}$ This specification can be extended without difficulty to include time invariant regressors.

${ }^{5}$ This technique was implemented by adding additional routines to the Ox version of DPD. Details are available from the authors on request.
} 


\section{Results}

We make use of the NESPD, Europe's largest wages/hours panel, based on establishment-level payroll records. Response bias is much less likely than in the case of employee-based surveys. The sample is restricted to full-time male workers who have worked in a single job and who worked paid overtime during at least one-year between 1985 to 1996 . Our panel is unbalanced, but the estimation routines described in the previous section accommodate such panels. As a result, we are able to include between 44,996 and 26,853 individuals in our estimation procedures.

Equation (2) has been estimated in four ways: first by Ordinary Least Squares (OLS), second by the Within estimator, thirdly using the combined difference - levels GMM estimator, and finally using the first-difference two-step GMM procedure modified to test for the existence of individual effects as described in the previous section. Results are shown in Table 1.

The OLS estimate of the coefficient on lagged overtime is 0.48 . This implies a relatively slow rate of adjustment of overtime hours to their desired level. In fact, it is an unbelievably slow rate since it implies that, on average, only 52 percent of desired changes in overtime hours are undertaken within a one-year period. However, our previous argument is that OLS underestimates this adjustment speed because it is confounding individual effects with adjustment processes. The individual effects are fixed components of individuals' habitual working time patterns. They are integral to the job match and not conditioned by demand-side shocks. 
Table 1 OLS, Within and GMM regression estimates of equation (2):

NESPD, 1990-1996 (full-time males)

\begin{tabular}{lcccccccc}
\hline & \multicolumn{3}{c}{ OLS Levels } & \multicolumn{2}{c}{ Within } & \multicolumn{2}{c}{ (Levels and Differences) } & \multicolumn{2}{c}{ (First Differences) } \\
\hline Lagged Overtime & 0.477 & {$[0.004]$} & -0.115 & {$[0.000]$} & 0.066 & {$[0.011]$} & 0.069 & {$[0.004]$} \\
$\mathrm{m}_{1}$ & -28.73 & {$[0.000]$} & -48.29 & {$[0.000]$} & 25.12 & {$[0.000]$} & -4.358 & {$[0.000]$} \\
$\mathrm{m}_{2}$ & 25.12 & {$[0.000]$} & -48.07 & {$[0.000]$} & -0.4591 & {$[0.646]$} & -0.852 & {$[0.394]$} \\
Wald & 25970 & {$[0.000]$} & 637 & {$[0.000]$} & 104.3 & {$[0.000]$} & 24.650 & {$[0.026]$} \\
Sargan & & & & & 21.61 & {$[0.483]$} & 11.860 & {$[0.690]$} \\
Individuals & 44996 & & 26853 & & 26853 & & 26853 & \\
\hline
\end{tabular}

Notes: Figures in brackets are p-values

$\mathrm{m}_{1}$ and $\mathrm{m}_{2}$ refer to first and second order autocorrelation coefficients respectively.

Equations also include the lagged standard hourly wage, standard weekly hours, industry and time dummies.

The instruments used in the GMM equations are all non-redundant lags and differences on the lagged dependent variable.

The $\mathrm{p}$ values on the coefficient on lagged overtime are from the 2-step estimator and use the Windmeijer (2000) correction for finite sample bias.

The coefficient on the lagged dependent variable in the Within estimates is -0.115 and like the OLS estimate is significant at the 1 per cent level. However, as mentioned previously, this estimator is likely to have a negative bias.

Table 1 also describes results from a two-step GMM procedure based on combining first differences and levels equations. It yields an estimate of 0.066 for the coefficient on lagged overtime hours and thus implies much more rapid, and realistic, adjustment speed than obtained using OLS. The revised estimate indicates that firms are able to eliminate the bulk of the gap (around 93 percent) between desired and actual overtime requirements within a one-year period. Table 1 also includes results for the two-step GMM differences 
equation which uses the residuals from the first step of the combined estimator, as is required for our test of individual effects.

The tests for first and second order serial correlation, $\mathrm{m}_{1}$ and $\mathrm{m}_{2}$ respectively, suggest strong serial correlation in both the OLS and Within estimators - as one might expect if the underlying data generating process involves individual effects and a dynamic lag structure. In contrast the GMM estimators fail to reject the null hypothesis of no secondorder autocorrelation, suggesting that the relevant lags (and differences) of the dependent variable are valid instruments. The Sargan tests for overidentification are easily satisfied under both variants of the GMM model. However, one should note Bowsher's (2000) argument that panels with large $\mathrm{T}$ may have artificially low rejection frequencies in Sargan tests because additional instruments (further lags of the level or differences in the dependent variable) are increasingly weak. Additional lagged instruments increase the degrees of freedom, and therefore the mean of the relevant chi-square distribution, without necessarily increasing the power of the test.

It would be expected that some workers change jobs in order to find an alternative income/hours combination that will be utility enhancing. To capture such effects, we included a dummy variable indicating whether the individual had changed jobs in the last twelve months. However, the variable was not significant in any equation. One explanation is that there are many alternative reasons why individuals may have changed their jobs. Another is that some individuals will seek shorter hours, while others will seek longer hours and there is therefore no clear prediction of the sign that this variable might take. If the desired change in hours is symmetrically distributed around zero, the variable 
is unlikely to be significant. Our lagged hourly wage and basic hours variables are insignificant in all but the OLS specification. This accords with the negligible effects of the wage on total hours worked reported by Kalwij and Gregory (2000) using the same dataset.

Our test for individual effects is based on the difference between the values of the Sargan tests in the differences and combined estimators. Its value, based on the seven additional instruments (and therefore seven degrees of freedom), used in the combined estimator, is 9.75. This is significant at the 20 per cent level. Jiminez-Martin (1998) points out that the power of this test increases with the number of strictly exogenous regressors and with a more balanced panel. Further, Bowsher's (2000) argument mentioned above will also be relevant to Sargan difference tests, such as that proposed above.

Nevertheless, our results jointly provide a plausible explanation of the behaviour of overtime hours. Both the OLS and Within estimators behave in the expected manner and the combined GMM model suggests that workers and jobs are matched to reflect both firm and individual preferences over working time. Our estimates suggest a very rapid adjustment to external shocks of those overtime hours that are not fixed. More generally, they point to seriously misleading interpretations of the role of overtime if individual effects are ignored. 


\section{Concluding remarks}

These results have potentially important implications for the existing working time literature. In workers-hours demand models, overtime is regarded as an adjustment mode on firms' intensive margins that serves to offset, for example, rises in fixed employment cost or cutbacks in the standard workweek. In more dynamic settings, changes in overtime hours have been regarded as providing an intensive margin buffer in the face of more sluggish employment and capital adjustments to output shocks. Our finding of individual effects in overtime working serves to blunt the impact of these interpretations. It is far more consistent with a long-term contractual role for overtime in the spirit of the seminal Lewis (1969) contribution.

The extent to which firms offer jobs of fixed lengths and are able to adjust standard rates to offset high/low premia renders active working time policy interventions to be either impotent or extremely costly. The current European Working Time Directive, with its voluntary opt-out clause, provides an example of the former outcome. Our results suggest that many workers will simply reject 48 weekly hours ceiling since they have self-selected into long-hours jobs. If the Directive were to be made mandatory then governments will have to expect industrial and collective bargaining costs associated with firms and workers being prevented from exercising long-hours preferences. 


\section{References}

Arellano (1993) On the testing of correlated effects with panel data, Journal of Econometrics 59: 87-97.

Arellano, M. and S. Bond. 1991. Some tests of specification for panel data: Monte Carlo evidence and an application to employment equations. Review of Economic Studies 58: 277-297.

Arellano, M. and O. Bover 1995. Another Look at the Instrumental-Variables Estimation of Error Component Models, Journal of Econometrics, 68: 29-52

Bell, D.N.F. and R.A.Hart. 2003. Wages, hours, and overtime premia: evidence from the British labor market. Industrial and Labor Relations Review (forthcoming).

Bils, M. 1987. The cyclical behavior of marginal cost and price. American Economic Review 77: 838-55.

Bond, S. 2002. Dynamic panel data models: a guide to micro data methods and practice. The Institute for Fiscal Studies, Department of Economics, UCL, Cemmap Working Paper Series, CWP09/02. , Institute for Fiscal Studies, London

Bond, S. and Windmeijer. 2002. Sample Finite Inference for GMM Estimators in Linear Panel Data Models, Cemmap Working Paper Series CWP04/02, Institute for Fiscal Studies, London

Bowsher, C.G. 2000 On Testing Overidentifying Restrictions in Dynamic Panel Data Models, Working Paper, Nuffield College, Oxford

Ehrenberg, R.G. 1971. Fringe benefits and overtime behavior. Lexington, Mass.: Heath. Department of Trade and Industry (1998) Guide to the Working Time Regulations. http://www.dti.gov.uk/er/work_time_regs/.

Fair, R. 1985, "Excess Labour and the Business Cycle", American Economic Review 75 1: $239-246$

Greene, W H. 2000. Econometric analysis. New Jersey: Prentice Hall International (4 ${ }^{\text {th }}$. Edition).

Hansen, L P. 1982. Large sample properties of Generalised Method of Moments estimators. Econometrica 50: 1029-1054.

Hart, R A and R J Ruffell. 1993. The cost of overtime hours in British production industries. Economica 60: 183-201. 
Holtz-Eakin (1988) Testing for Individual Effects in Autoregressive Models. Journal of Econometrics 39: 297-307.

Incomes Data Services (1997), Overtime, Study 617, London: Income Data Services Ltd. Incomes Data Services (1999), Annual Hours, Study 674, London: Income Data Services Ltd.

Incomes Data Services (2002), Annual Hours, Study 721, London: Income Data Services Ltd.

Jiminez-Martin, D. 1998. On the Testing of Heterogeneity Effects in Dynamic Unbalanced Panel Data Models, Economics Letters, 58: 157-163

Kalwij, A. and M. Gregory 2000. Overtime Hours in Great Britain over the Period 19751999: A Panel Data Analysis, IZA Discussion Paper 153, IZA, Bonn

Killingsworth, M.R. 1983. Labor supply. Cambridge: Cambridge University Press.

Lewis, H.G. 1969. Employer interests in employee hours of work. Mimeo. University of Chicago.

Nadiri, M.I. and S. Rosen. 1973. A disequilibrium model of the demand for factors of production. New York: National Bureau of Economic Research.

OECD Employment Outlook. 1998. Working hours: latest trends and policy initiatives. Chapter 5. Paris: OECD.

Topel, R.H. 1982. Inventories, layoffs, and the short-run demand for labor. American Economic Review 72: 769-87.

Rosen, S. 1974. Hedonic prices and implicit markets: product differentiation in pure competition, Journal of Political Economy 82: 34-55.

Trejo, S J. 1991. Compensating differentials and overtime pay regulations. American Economic Review 81: 719-70.

Windmeijer, F. 2000. A finite sample correction for the variance of linear two-step GMM estimators. IFS working paperW00/19 (www.ifs.org.uk), London: The Institute for Fiscal Studies. 


\section{IZA Discussion Papers}

\begin{tabular}{|c|c|c|c|c|}
\hline No. & Author(s) & Title & Area & Date \\
\hline 750 & $\begin{array}{l}\text { R. Hujer } \\
\text { M. Caliendo } \\
\text { S. Thomsen }\end{array}$ & $\begin{array}{l}\text { New Evidence on the Effects of Job Creation } \\
\text { Schemes in Germany - A Matching Approach } \\
\text { with Threefold Heterogeneity }\end{array}$ & 6 & $04 / 03$ \\
\hline 751 & $\begin{array}{l}\text { L. Borghans } \\
\text { B. ter Weel }\end{array}$ & $\begin{array}{l}\text { Are Computer Skills the New Basic Skills? The } \\
\text { Returns to Computer, Writing and Math Skills in } \\
\text { Britain }\end{array}$ & 5 & $04 / 03$ \\
\hline 752 & $\begin{array}{l}\text { N. Malchow-Møller } \\
\text { J. R. Skaksen }\end{array}$ & $\begin{array}{l}\text { Skill-Biased Technological Change in Denmark: } \\
\text { A Disaggregate Perspective }\end{array}$ & 5 & $04 / 03$ \\
\hline 753 & $\begin{array}{l}\text { S. Burgess } \\
\text { H. Turon }\end{array}$ & $\begin{array}{l}\text { Unemployment Equilibrium and On-the-Job } \\
\text { Search }\end{array}$ & 1 & $04 / 03$ \\
\hline 754 & H. Turon & $\begin{array}{l}\text { Separability of Duration Dependence and } \\
\text { Unobserved Heterogeneity }\end{array}$ & 1 & $04 / 03$ \\
\hline 755 & T. Dohmen & $\begin{array}{l}\text { In Support of the Supporters? Do Social Forces } \\
\text { Shape Decisions of the Impartial? }\end{array}$ & 7 & $04 / 03$ \\
\hline 756 & $\begin{array}{l}\text { N. Datta Gupta } \\
\text { R. Oaxaca } \\
\text { N. Smith }\end{array}$ & $\begin{array}{l}\text { Swimming Upstream, Floating Downstream: } \\
\text { Comparing Women's Relative Wage Positions in } \\
\text { the U.S. and Denmark }\end{array}$ & 5 & $04 / 03$ \\
\hline 757 & J. Hunt & Teen Births Keep American Crime High & 5 & $04 / 03$ \\
\hline 758 & $\begin{array}{l}\text { J. Lise } \\
\text { S. Seitz } \\
\text { J. Smith }\end{array}$ & $\begin{array}{l}\text { Equilibrium Policy Experiments and the } \\
\text { Evaluation of Social Programs }\end{array}$ & 6 & $04 / 03$ \\
\hline 759 & E. P. Lazear & The Peter Principle: A Theory of Decline & 1 & $04 / 03$ \\
\hline 760 & E. P. Lazear & Entrepreneurship & 5 & $04 / 03$ \\
\hline 761 & E. P. Lazear & $\begin{array}{l}\text { Output-Based Pay: Incentives, Retention or } \\
\text { Sorting? }\end{array}$ & 5 & $04 / 03$ \\
\hline 762 & $\begin{array}{l}\text { M. Gerfin } \\
\text { R. E. Leu }\end{array}$ & $\begin{array}{l}\text { The Impact of In-Work Benefits on Poverty and } \\
\text { Household Labour Supply - A Simulation Study } \\
\text { for Switzerland }\end{array}$ & 3 & $04 / 03$ \\
\hline 763 & $\begin{array}{l}\text { M. Biewen } \\
\text { S. P. Jenkins }\end{array}$ & $\begin{array}{l}\text { Estimation of Generalized Entropy and Atkinson } \\
\text { Inequality Indices from Complex Survey Data }\end{array}$ & 5 & $04 / 03$ \\
\hline 764 & P. A. Puhani & $\begin{array}{l}\text { A Test of the 'Krugman Hypothesis' for the } \\
\text { United States, Britain, and Western Germany }\end{array}$ & 2 & $04 / 03$ \\
\hline 765 & W. Schnedler & $\begin{array}{l}\text { On the Prudence of Rewarding A While Hoping } \\
\text { for B }\end{array}$ & 5 & $04 / 03$ \\
\hline 766 & $\begin{array}{l}\text { D. N. F. Bell } \\
\text { R. A. Hart }\end{array}$ & $\begin{array}{l}\text { How Important Is Guaranteed or Institutionalised } \\
\text { Overtime? }\end{array}$ & 5 & $04 / 03$ \\
\hline
\end{tabular}

An updated list of IZA Discussion Papers is available on the center's homepage www.iza.org. 